Kissimmee, FL

\title{
Computational and Experimental Study of Plume and Shock Interaction Effects on Sonic Boom in the NASA Ames 9x7 Supersonic Wind Tunnel
}

\author{
Courtney S. Winski*, Melissa B. Carter ${ }^{\dagger}$, Alaa A. Elmiligui ${ }^{\ddagger}$ \\ NASA Langley Research Center, Hampton, VA 23681, USA \\ Jason M. Pearl§ \\ University of Vermont, Burlington, VT 05401, USA \\ Sudheer N. Nayani** \\ Analytical Services \& Materials, Inc., Hampton VA 23666, USA \\ Donald Durston ${ }^{\dagger \dagger}$ \\ NASA Ames Research Center, Moffett Field, California, 94035, USA
}

\begin{abstract}
A wind tunnel test was performed in the NASA Ames 9x7 Supersonic Wind Tunnel focusing on the shock waves traveling through and interacting with an exhaust nozzle plume. This experimental study was conducted to develop and validate the CFD capability required to accurately include nozzle flow with impinging shock effects on near field and ground-propagated sonic boom signatures. The model was made to be generic, and included a simple nozzle shape, two different aft decks, and a few generic horizontal tails. High pressure air was pumped through a nozzle at various nozzle pressure ratios (NPR) to represent the engine plume in flight. The three different aft body representations each created a different shock wave signature that passed through the plume. An aft deck configuration, where part of the aircraft shields the nozzle plume, was also tested. Retroreflective Background-Oriented Schlieren (RBOS) was used to obtain schlieren images of the flow field around the model and behind the model. This study compares wind tunnel data and numerical simulations conducted by the NASA Tetrahedral Unstructured Software System CFD code, USM3D.
\end{abstract}

\footnotetext{
* Aerospace Engineer, Configuration Aerodynamics Branch, Mail Stop 499, AIAA Senior Member.

† Aerospace Engineer, Configuration Aerodynamics Branch, Mail Stop 499, AIAA Associate Fellow.

‡ Aerospace Engineer, Configuration Aerodynamics Branch, Mail Stop 499, AIAA Senior Member.

$\S$ Graduate Student, College of Engineering and Mathematical Sciences, AIAA Student Member.

${ }^{* *}$ Senior Scientist, CFD Group, 107 Research Drive, AIAA Associate Fellow.

t† Aerospace Engineer, Experimental Aero-Physics Branch, Moffett Field, AIAA Senior Member.
} 


\section{Nomenclature}

BL body length

CFD Computational Fluid Dynamics

CST Commercial Supersonics Technology

$\Delta \mathrm{P} \quad$ Overpressure, $\left(\mathrm{P}_{\text {measured }}-\mathrm{P}_{\infty}\right)$

$\Delta \mathrm{P} / \mathrm{P}_{\infty} \quad$ pressure signature magnitude, $\left(\mathrm{P}_{\text {rail }}-\mathrm{P}_{\infty}\right) / \mathrm{P}_{\infty}$

ESP electronically scanned pressure

$\mathrm{H}_{\text {nose }} \quad$ height of the model nose over the pressure rail, inches

NPR nozzle pressure ratio, $\mathrm{P}_{\mathrm{T}, \mathrm{noz}} / \mathrm{P}_{\infty} * 144 \mathrm{in}^{2} / \mathrm{ft}^{2}$

$\mathrm{P}_{\infty} \quad$ freestream static pressure, PSF

Prail pressure obtained from the rail, PSF

$\mathrm{P}_{\mathrm{T}} \quad$ total pressure, $\mathrm{PSF}$

$\mathrm{P}_{\mathrm{T}, \mathrm{noz}} \quad$ total pressure in the nozzle plenum, PSI

PSF pounds per square foot

PSI pounds per square inch

Q dynamic pressure, PSF

RBOS Retroreflective Background-Oriented Schlieren

$\operatorname{Re} \quad$ unit Reynolds number, per foot

$\mathrm{T} \quad$ static temperature, $\operatorname{degF}$

$\mathrm{X}$ extension distance of linear actuator ram on the model support system, inches

$\mathrm{r} \quad$ radius of model, inches

$\mathrm{x} \quad$ distance measured along longitudinal axis from model nose, inches

\section{Introduction}

The Commercial Supersonics Technology (CST) project, under the NASA Advanced Air Vehicles Program, conducts research to solve a number of different challenges related to supersonic flight. Challenges related to supersonic flight include lightweight engines/airframes, supersonic cruise efficiency, emissions, sonic boom, airport noise, and multidisciplinary design. Several studies have been conducted to reduce the noise from a sonic boom, including shaping of the airframe [1].

Coalescing shock waves and expansion fans formed by aircraft components generate a sonic boom. These coalescing shock waves and expansion fans create an $\mathrm{N}$-wave, which consists of a rapid rise in pressure, followed by a slow drop-in pressure, and then a rapid return to 
atmospheric pressure (figure 1). The pressure vs. time graph at an observer's location resembles a letter "N," as shown in Figure 1.

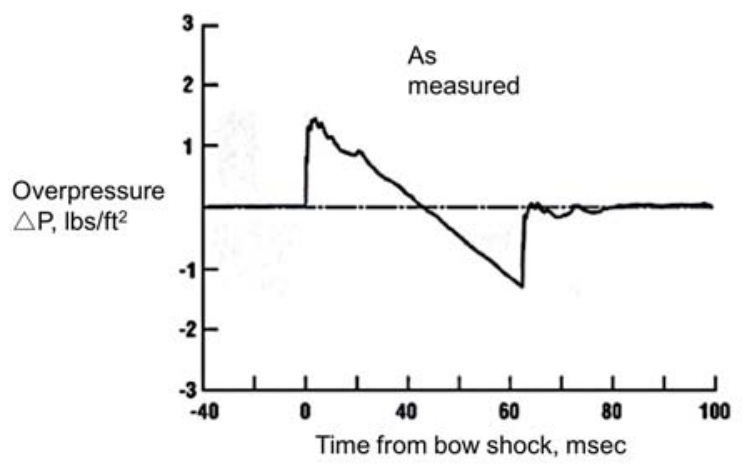

Figure 1. Measured F-5E boom N-wave (1).

CFD tools are being used to predict shocks and sonic boom loudness, however, the impact of the empennage of an aircraft is not as well understood as the impact from the forebody. The main challenge comes from the aircraft shocks interacting with jet plumes, and how that interaction affects the boom signature [2].

Early work on the contributions of an exhaust nozzle on sonic boom was reported by Putnam and Capone [3], and by Barger and Melson [4]. Their experiment was conducted in a wind tunnel with a fully expanded nozzle. Castner [5] later performed a CFD analysis that showed the impact that either an overexpanded or an underexpanded nozzle flow had on the shape of the N-wave. Testing was then conducted at the NASA Glenn Research Center in the $1 \mathrm{x} 1$ Supersonic Wind Tunnel to understand the effects of a shock passing through a nozzle flow [6]. The plume and shock interaction study was developed to collect data for CFD validation where a nozzle plume passed through the shock generated from the wing or tail of a supersonic vehicle. Major findings of the study demonstrated how the interaction of the jet plume caused a thickening, or widening [6], of the shock generated by the wedge or aft deck, and movement of the shock location with increasing nozzle pressure ratio. There were, however, some concerns with the data. Due to the small scale of the tunnel, it was desired to have an increased fidelity of the model to be used in CFD assessment. Also, the static pressure probe data (the main data from the test) were corrected based on a post-test study. It was therefore desired to run a similar test in a larger facility, the NASA Ames 9by 7-Foot Supersonic Wind Tunnel, in hopes of improving the data quality. 
For this study, a wind tunnel test was conducted in the NASA Ames 9- by 7-Foot Supersonic Wind Tunnel $(9 \times 7)$. High pressure air was pumped through a nozzle at various nozzle pressure ratios (NPRs) to represent the engine plume in flight. Three different aft body representations, each creating a different shock wave signature that passed through the plume, were tested. An aft deck configuration, where part of the aircraft shields the nozzle plume, was also tested. The pressure signatures created by the plume and shock generators, were captured using a 14-inch pressure rail. Additionally, for some of the runs, a pressure rake was mounted behind the nozzle exit to capture the nozzle exit total pressure profile. Retroreflective Background-Oriented Schlieren (RBOS) was also used to obtain schlieren images of the flow field around the model and behind the model, where the shock from the shock generators passed through the plume.

The main objective of the study was to identify jet plume and plume-shock interaction effects and identify the potential for those effects to impact a low boom aircraft design. The study was also used to develop and validate the CFD capability required to accurately include nozzle flow with impinging shock effects on near field and ground-propagated sonic boom signatures. This paper will discuss the experimental set-up, study and compare computational and experimental results for plume and shock interaction effects on sonic boom.

\section{Test Setup}

\section{A. Wind Tunnel}

The Ames 9- by 7-Foot Supersonic Wind Tunnel is part of the Unitary Plan Wind Tunnel [7,8] complex at the NASA Ames Research Center at Moffett Field, California. It is a continuous flow, closed-circuit, variable-density tunnel, equipped with an asymmetric sliding-block nozzle for setting Mach number. The floor of the wind tunnel test section is part of the nozzle block and translates axially (streamwise) to vary the nozzle throat area while the contoured tunnel ceiling remains stationary. This combination provides a Mach number range from 1.55 to 2.5 . The sidewalls are flat and parallel through the nozzle and test section. The asymmetric nozzle results in slightly larger stream angle variations in the vertical plane, on the order of 0.25 to 0.5 degrees, whereas the stream angle in the horizontal plane is generally less than 0.2 degrees. The angle-of-attack plane is therefore horizontal (Figure 2), and the model support strut at the rear of the test section is horizontal as well (Figure 3). Models are thus normally mounted with wings vertical, and the strut translates horizontally to keep the model in the center of the tunnel as the pitch angle is changed. The 
Kissimmee, FL

forward end of the strut center body pivots by means of a mechanical joint (knuckle-sleeve system) to achieve any combination of angle of attack or sideslip within a $15^{\circ}$ cone angle. Throughout this report, the model distance from the rail on the sidewall of the tunnel is referred to as "height" even though in reality it is a horizontal distance in the $9 \mathrm{x} 7$ wind tunnel.

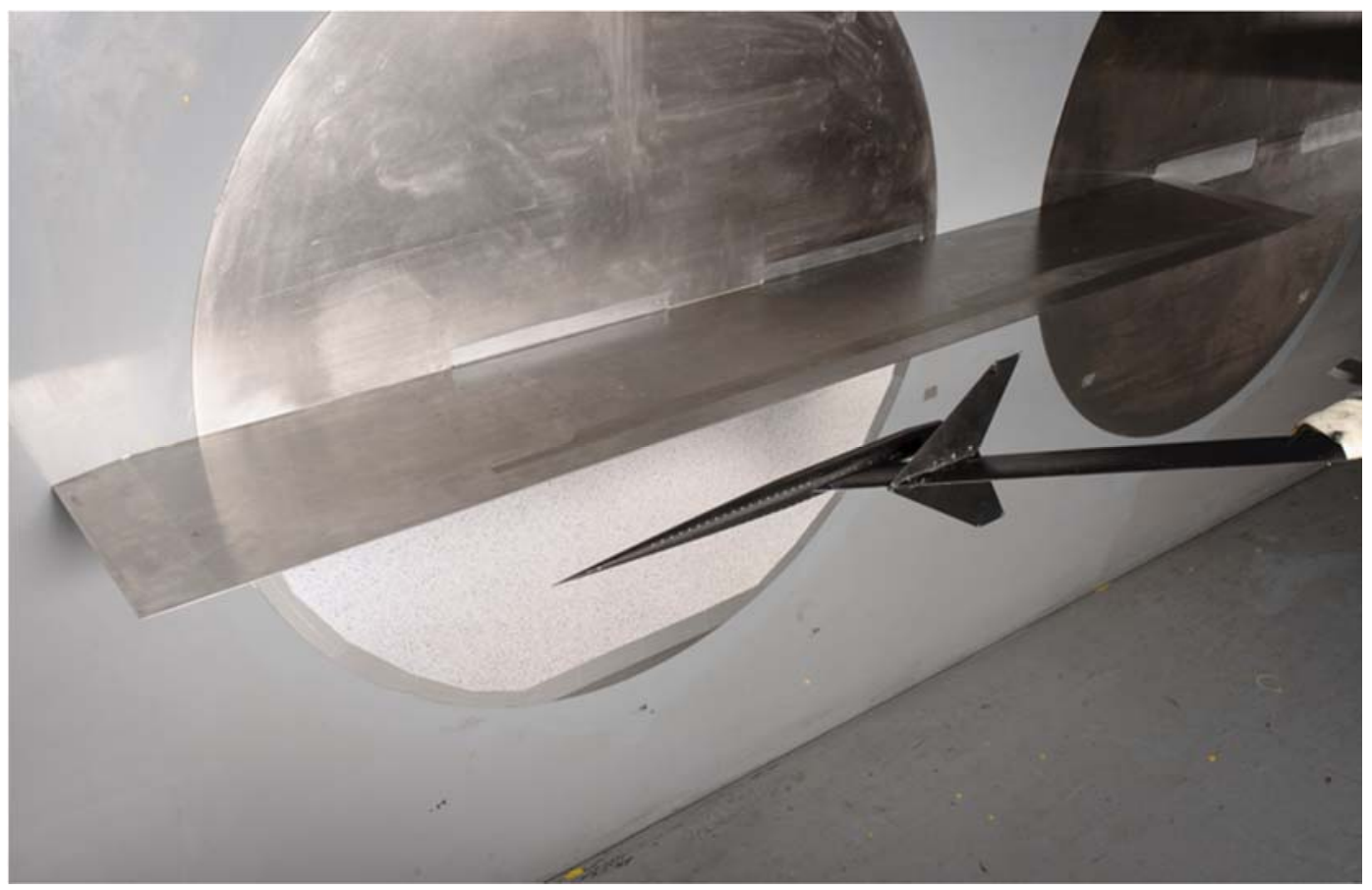

Figure 2. Photograph of the plume/shock interaction model above the 14" pressure rail, with the 25-D tail installed on the blade strut. 


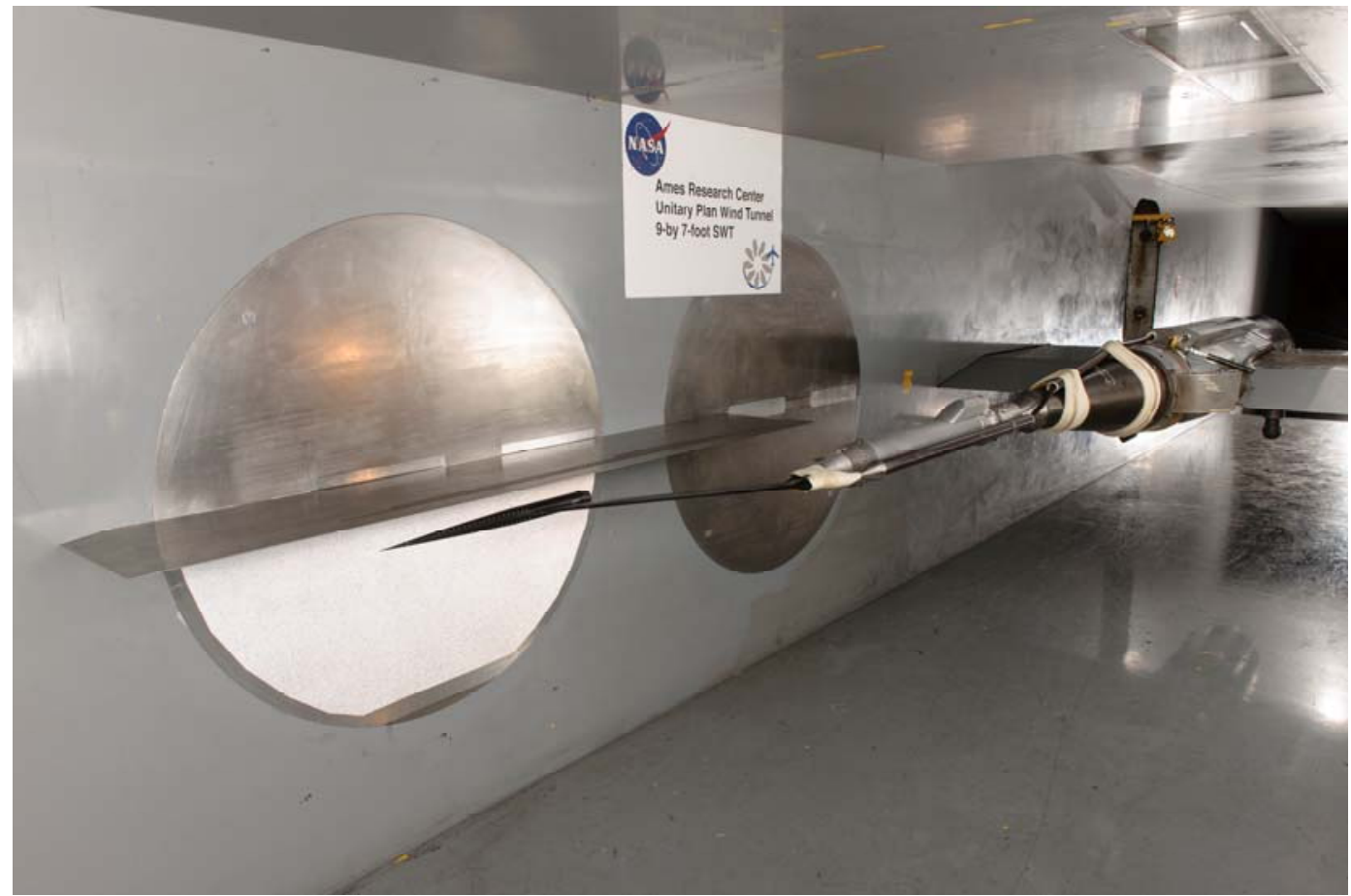

Figure 3. Photograph of the 9x7-Foot wind tunnel strut with nozzle only configuration installed above the 14" rail.

\section{B. Model}

The primary model was a 1.5" exit diameter nozzle, based off of the Putnam 6 nozzle [3], with modifications. A long curved, tapered nose section was designed to minimize the interference of the nose shock on the pressure rail while ensuring it was large enough for manufacturing. The nose contour was based on the Carlson Model 6 nose shape [9], using equation 1 below. A flow-through strut was designed to mount the nozzle while high pressure air was run through it into a plenum in the model. From there, the flow traveled through a choke plate then through a convergent/divergent nozzle to produce supersonic flow. Figure 4 shows the internal flow path through the strut, and the nozzle. Flow was varied to allow for various NPR's, from overexpanded to underexpanded exhaust. There were three exit nozzle lengths, for positioning the plume, dependent on the shock generator used. Internal instrumentation included a static pressure tap and rake with total pressure and total temperate measurements.

$$
r=x \sqrt{\frac{0.025}{\pi}(1-0.3 x)}
$$




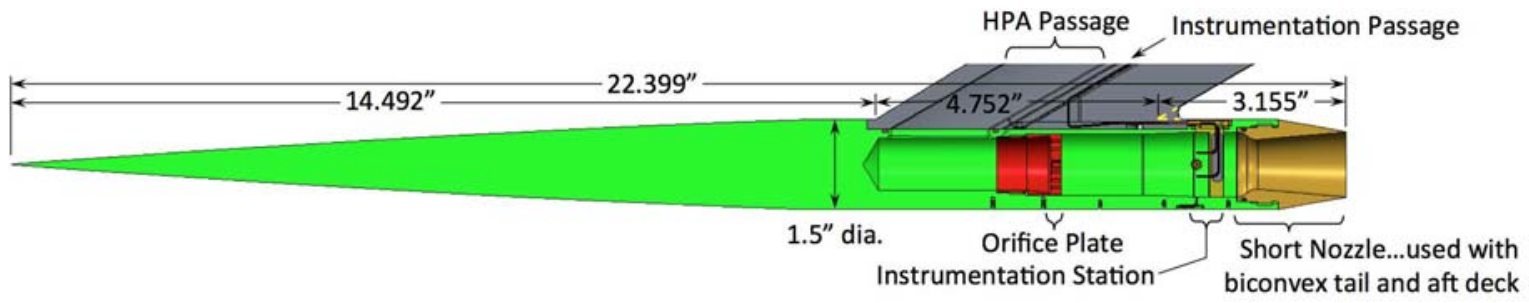

Figure 4. Internal cut-away CAD view of the lower part of the blade strut, the nozzle body, and the short nozzle.

The model was attached to the tunnel by a 60-deg. swept strut, 12.5 " away from the tunnel support system. A total of five model configurations were tested: a baseline nozzle only configuration, an aft deck mounted under the nozzle, and 3 shock generators mounted on the strut. The shock generators were designed to create a shock that would intersect the jet plume, and the aft deck was designed to shield the boom signature from nozzle exit shocks. The three shock generators tested, which are described below, were the double wedge, biconvex and 25-D, seen in figure 5.

The double wedge shock generator was a scaled-up version (1.5 times) of the shock generator used in the Glenn Research Center (GRC) 1x1 test [6], to allow for a similar test case between the two tests. The double wedge generated a strong shock, but it is not representative of a modern day horizontal tail design. The biconvex shock generator was modeled to represent a small horizontal tail. It was patterned after a low-boom wing-tail (LBWT) [10] model designed in the early 1990s. The 25-D tail was taken from the Langley 25-D low-boom flight demonstrator configuration [11], and was tested as a representation of a modern day low boom vehicle tail.

The aft deck model, seen in figure 5, was designed to resemble an aft deck mounted under a nacelle, used to provide shielding of the engine nozzle exit shocks, which could potentially be used on a low boom design to minimize the impact of the engine on a sonic boom. The aft deck was sized for shielding at low NPRs and no shielding at higher NPRs [12].

Three separate nozzle lengths were used, depending on the shock generator or aft deck used. The nozzle length was selected to line up the shock correctly with the jet plume. The biconvex tail and aft deck configurations used the short nozzle. The 25-D Tail used the 
medium length nozzle, which was 1.928 " longer than the short nozzle. The double wedge configuration used the long nozzle, which was 2.928 " longer than the short nozzle.

25-D Tail

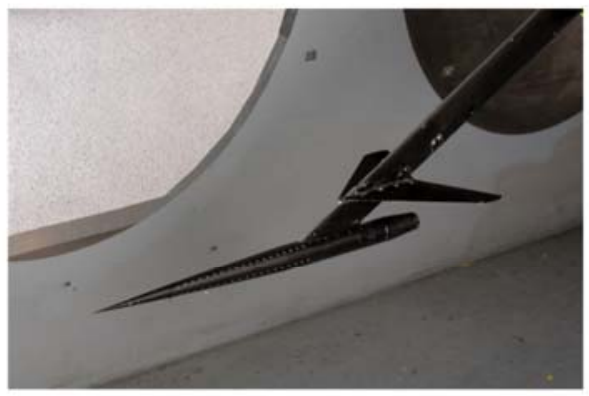

Nozzle Only

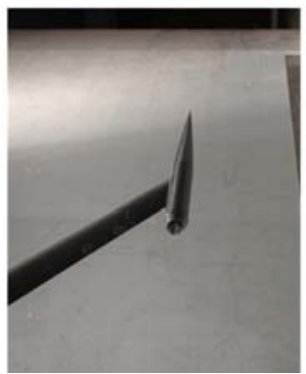

Biconvex Tail

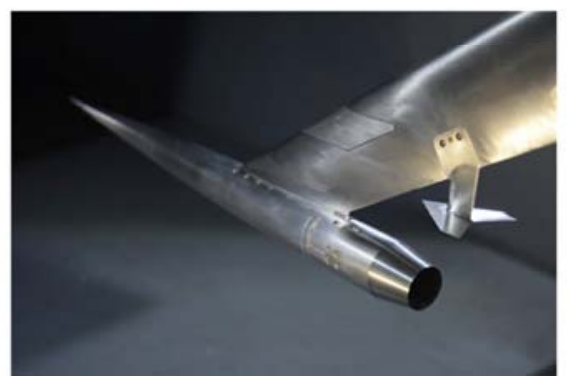

Figure 5. Photographs of the model configurations, 25-D tail, swept aft deck, nozzle alone, biconvex tail, and the double wedge.

\section{Instrumentation}

The 14" pressure rail was used to measure the model's boom signature in the tunnel. The rail, pictured in Figure 2, stands 14 inches off of the tunnel wall. The rail width is 90 inches long, with an instrumented section that is 66 inches long. The instrumented section has 420 pressure orifices of 0.015 -inch diameter, spaced $4 \mathrm{~mm}$ (approximately $0.1575 \mathrm{in}$.) apart along its tip. The pressure tubes are run to 64-port, 5-psid electronic pressure scanners (ESP) modules, with a reduced range of 1.67-psid, outside of the tunnel for measurement. The rail has a tip radius of 0.05 inches, and a 1 inch wide base [13]. This pressure rail has been used in numerous tests for measuring sonic boom signatures.

The rail height was selected to prevent contamination of the aft part of a model's signature measured on the rail by reflections off the tunnel wall of model shock waves from the forward part of the model. The height of $14 \mathrm{in}$. provides reflection-free data for model lengths of 35 and 43 in. at Mach 1.6 and 1.8, respectively. 


\section{Internal Nozzle Measurements}

Internal to the model, between the choke plate and the nozzle exit was a rake with a total temperature and total pressure measurement (Figure 4). The total pressure was measured on a 50-psi transducer located at the rear of the tunnel strut. There was a static pressure port on the wall of the nozzle internal flow path, for measuring static pressure. The static pressure port was measured on a 15-psid scanner, located at the rear of the tunnel strut. There were also two static temperature thermocouples on the sides of the nozzle body wall.

Upstream of the nozzle, in the high-pressure air, internal flow path, there was one static pressure port located at the bottom of the blade strut. This allowed for a measurement of the supply air entering the nozzle body. The pressure at this location was higher than the pressure downstream of the orifice plate, so a dedicated high-pressure transducer, located at the top of the blade strut, was used for measurement.

\section{E. Photogrammetry}

The model had neither an angle measurement, nor a balance from which to calculate sting deflections. Consequently, model angle was estimated based on tunnel strut setting during the test, and measured with photogrammetry (though not processed in real time). Post-test processing of the photogrammetry provided measurements of the model angle of attack, angle of sideslip, roll angle, and X, Y, Z position in the tunnel for every run. The model was painted flat black, with white dots painted over the black paint in various locations for photogrammetry targets. Two cameras were positioned on the upstream, south side window to view the model over the full movement range.

The processing of the photogrammetry was not as automated as was originally hoped. Over 86,000 photogrammetry images were acquired during testing, however only about 12,000 of the images were processed, because it was required for a person to look at and verify or adjust the found-target locations. These 12,000 images represented about half of the averaged signature runs (acquired in X-sweeps, described later), and from these processed images, a linear fit of the angles and positions were computed for these averaged runs, and groups of these linear fits were averaged by model configuration and Mach number to apply to all the runs of the test. More information on this can be found in reference 14. 


\section{F. Retroreflective Background-Oriented Schlieren}

The windows on the north side of the tunnel wall, were replaced with window blanks to allow for the installation of the 14" pressure rail, and thus conventional schlieren imaging with light passing through windows on both sides of the tunnel could not be used. In place of this, Retroreflective Background-Oriented Schlieren (RBOS) [2,15] was used to provide visualization of the shocks, and flow field interactions around the model. A highly reflective material was applied in the area below the pressure rail, and painted with a black speckle pattern, and the RBOS camera and lights were located in the upstream window on the south side of the tunnel. Special imaging equipment and processing algorithms were used to visualize gradients in the flow based off of the refraction index and distortion of the reflective material and the speckles. For more information on the RBOS technique used see references 2 and 15 .

\section{Experimental Data Collection}

Wind tunnel data was obtained at Mach 1.6 and 2.0 with the tunnel nominal conditions listed in Table 1. In addition to Mach number, there were four different physical settings for the model: height, angle of attack, roll angle, and longitudinal (x) position. Model height was set at 4 specified heights ( $\left.\mathrm{H}_{\text {nose }}\right)$ above the rail $(8,15,23$, and 30 inches). Angle of attack was set at one of three specified settings $(0,3$, and 4 degrees) while roll was also varied $(0$, 15,25 , and 30 degrees) to give sonic boom signatures on and off-track. Once the model angles in relation to the rail were set, the model was moved through an x-sweep, stopping at increments along the pressure rail, to take averaged data points for 10 seconds. Spatial averaging was used on the data points taken in the $\mathrm{x}$-direction along the rail to produce a signature with reduced effects from the tunnel flow field spatial distortions [16]. Reference runs were taken with the model out of "view" of the pressure rail, and then subtracted from the data runs, to remove tunnel effects from the signatures (Equation 2). The two-sigma uncertainty of the experimental data was calculated using the method described in reference 16.

$$
\Delta \mathrm{P} / \mathrm{P}_{\infty}=\left[\left(\mathrm{P}_{\text {rail }}-\mathrm{P}_{\infty}\right) / \mathrm{P}_{\infty}\right]_{\text {data run }}-\left[\left(\mathrm{P}_{\text {rail }}-\mathrm{P}_{\infty}\right) / \mathrm{P}_{\infty}\right]_{\text {reference run }}
$$

NPR was calculated using the internal nozzle measurements. NPR was varied from 1 (no flow) up to 14 (underexpanded), with most cases being run at an NPR of 4 (overexpanded), 8 (design), and 14 (underexpanded). 
Table 1. Tunnel Nominal Conditions at a Given Mach Number.

\begin{tabular}{|l|l|l|l|l|l|}
\hline Mach & $\mathrm{P}_{\mathrm{T}}, \mathrm{PSF}$ & $\mathrm{P}_{\infty}, \mathrm{PSF}$ & $\mathrm{Re}, / \mathrm{ft}$ & $\mathrm{Q}, \mathrm{PSF}$ & $\mathrm{T}, \operatorname{degF}$ \\
\hline 1.6 & 1800 & 423 & $3.539 \times 10^{\wedge} 6$ & 759 & -98.5 \\
\hline 2 & 2100 & 268 & $3.559 \times 10^{\wedge} 6$ & 751 & -148.7 \\
\hline
\end{tabular}

\section{Numerical Techniques}

\section{A. Grid Generation and CFD Code Information}

This CFD study used the NASA Tetrahedral Unstructured Software System (TetrUSS) for all the computations. TetrUSS, created and maintained at the NASA Langley Research Center, includes an unstructured grid generation program called VGRID, a post-processor named POSTGRID, and the flow solver USM3D [17].

VGRID is an interactive, or batch, tetrahedral unstructured grid generation program. The grids produced by VGRID are suitable for computing Euler or Navier-Stokes flow solutions. The grid spacing is related to the strength of user-defined sources placed in the domain. The methodology is based on the Advancing-Front method (AFM) [18] and the AdvancingLayers method (ALM) [19]. Both techniques are based on marching processes in which tetrahedral cells grown on an initial triangular boundary mesh and gradually form in the field around the geometry. Once the advancing front process is completed in VGRID, an additional post-processing step is required using POSTGRID to close any open pockets and to improve grid quality.

In 2008, a new version of VGRID was introduced [20]. Software updates to VGRID included growth rates, surface sources, and volume sources. The outer boundary sources were no longer required for grid growth rates. The outer boundary sources were replaced with a user specified growth rate of the grid that dictates how the grids grow outward from the aircraft and their maximum size. Additionally, new volume source types became available in VGRID. In the older version of VGRID, only point and line sources were available. Now, users can define sources that are based on a sphere, a cylinder, or a cone.

The USM3D code [21] is a cell-centered, finite-volume Navier-Stokes flow solver that uses Roe flux-difference splitting [22] to compute inviscid flux quantities across the faces of the tetrahedral cells. Several options for turbulent closure are available: the one-equation Spalart-Allmaras (S-A) model [23] (with and without a wall function), and several two- 
equation models, including Menter's Shear Stress Transport (SST) model [24]. The minmod limiter, used for supersonic conditions, was used during this study to ensure numerical stability. For the USM3D CFD cases conducted in this study, the k- $\varepsilon$ Sarkar PD turbulence model was used [25]. This turbulence model has done well for supersonics jets.

B. Grid Generation Methodology:

The grid generation process described herein is a two-step process. In step one, an inner grid is generated close to the configuration. In step two, a collar grid is added to the inner grid using the Boom Grid (BG) method.

\section{Inner Grid:}

The inner or base grid is generated by VGRID. The body is brought down as close to the outer boundary as possible. Typically, it is placed in such a way that there is $(0.02 *$ body length) clearance between the wing tip and the outer boundary.

1. The first cell height, $\delta_{1}$, used is $1.0 \mathrm{e}-05$ inches.

2. The boundary layer growth rate parameters, rate $1\left(\mathrm{R}_{1}\right)$ and rate $2\left(\mathrm{R}_{2}\right)$, are 0.15 and 0.05 and are used with the following equation to determine the cell spacing within the boundary layer, $\delta_{\mathrm{j}}=\delta_{1} *\left(1+\mathrm{R}_{1} *\left(1+\mathrm{R}_{2}\right)\right)^{\mathrm{j}-1, \mathrm{j}-1}$

3. The cell spacing on the outer boundary is a variable along the $\mathrm{x}$-direction. Typically, it is $0.0025^{*}$ body length (or $1 / 400^{\text {th }} \mathrm{BL}$ ) from the nose to the end of plume cylindrical source. The cell spacing is increased to $0.01 * \mathrm{BL}$ outside that region, which includes the inlet boundary face to the nose and the end of the plume source to the exit boundary.

4. The inlet boundary is typically 1 body length in front of the nose and the exit boundary is 5 body lengths from the end of the body.

5. All the spacings on the fuselage and the lifting surfaces conform to the AutoSrc specification [26].

Boom (Collar) Grid:

1. The NASA Langley code, BG, is used to add the outer collar to the inner grid.

2. The collar grid is stretched and sheared along the Mach angle. The stretching is per certain stretching parameters in the BG code [26]. These parameters have been optimized based on working with a number of supersonic configurations.

3. The radial outer boundary of the collar grid is typically 5 or 10 body lengths based on the requirement. 
Kissimmee, FL

4. The number of layers in the collar grid is typically between 50 and 100 .

Figures 6 and 7 below show the surface mesh of the inner grid and boom grid in the $y=0$ plane, respectively.

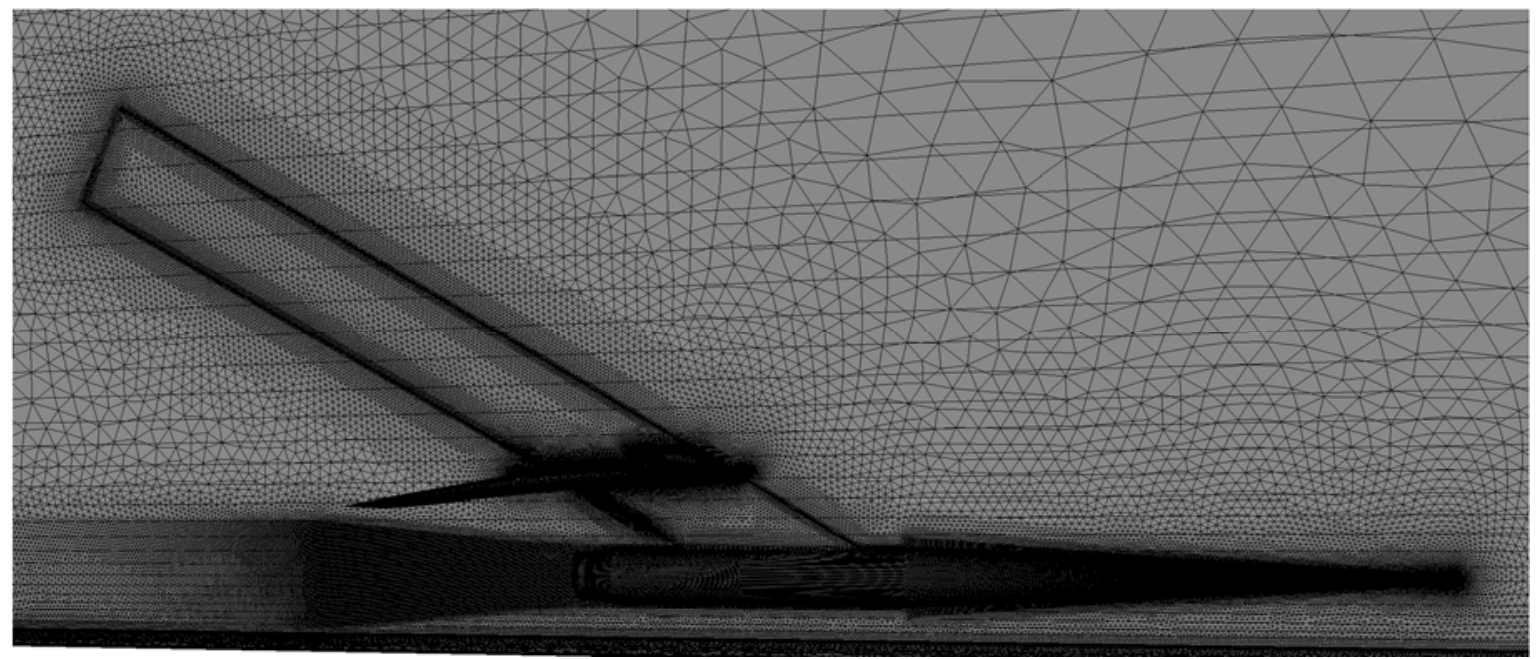

Figure 6. Surface mesh of the inner grid (25D Configuration). 
Kissimmee, FL

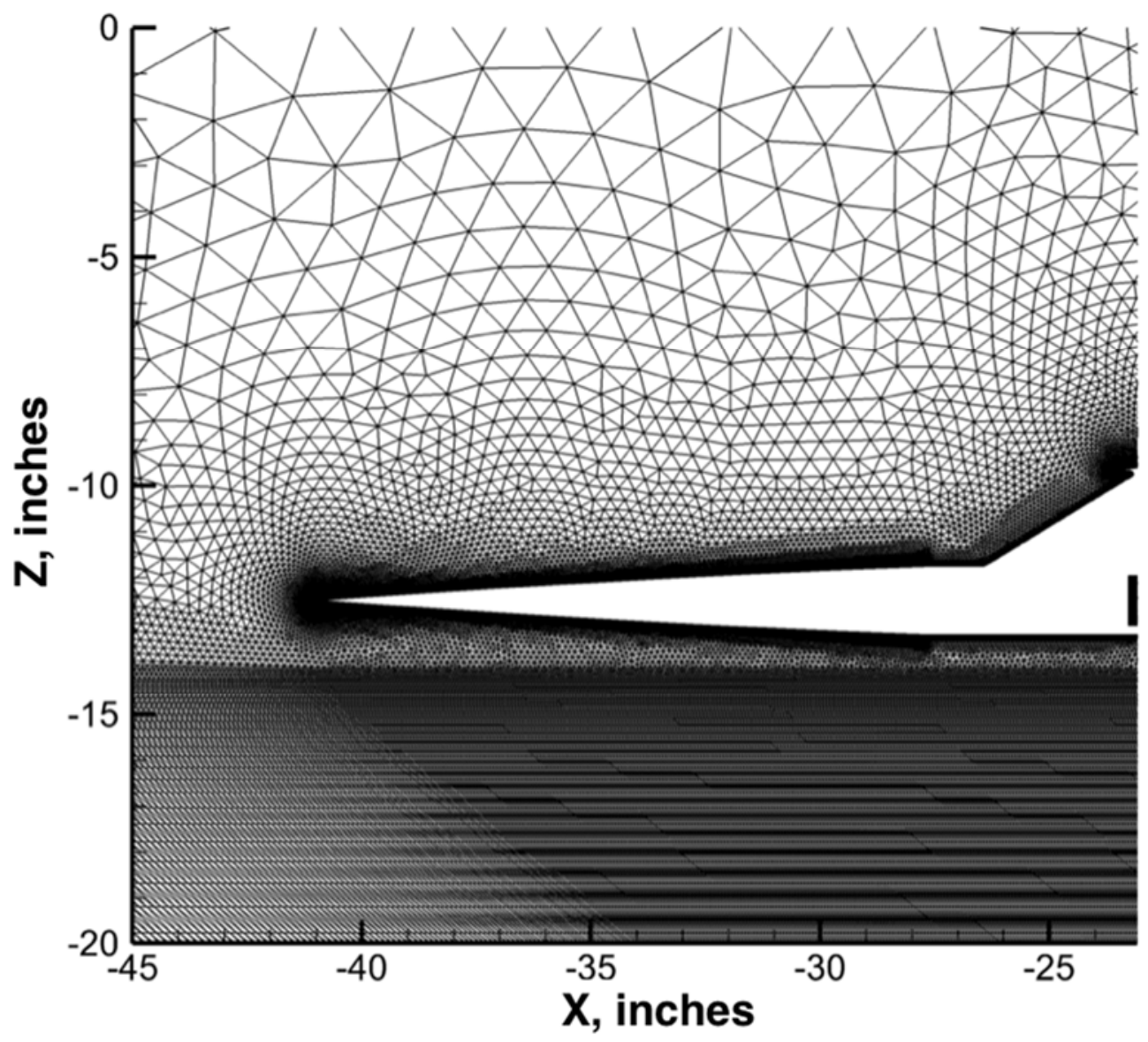

Figure 7. Boom grid of the $25 \mathrm{D}$ configuration $(\mathrm{y}=\mathbf{0}$ plane $)$.

\section{Results}

All of the results shown below were obtained at an angle of attack, yaw angle, and roll angle of 0 degrees and an NPR of 8, except the double wedge configuration, which is shown at an NPR of 10. All of the configurations were run at Mach 1.6 and unit Reynolds number equal to $3.5 \times 10^{6}$ per $\mathrm{ft}$, except the double wedge and 25 -D tail configuration, which were run at Mach 2.0 and unit Reynolds number equal to $3.5 \times 10^{6}$ per $\mathrm{ft}$, the double wedge was run to match the conditions in the Glenn $1 \times 1$ wind tunnel.

In this paper, the pressure signature represents the signature of overpressure coefficient, which is a dimensionless parameter that describes the relative pressures throughout the flow field and is defined as $\Delta \mathrm{P} / \mathrm{P}_{\infty}=\left(\mathrm{P}-\mathrm{P}_{\infty}\right) / \mathrm{P}_{\infty}$. Error bars on the experimental data show $+/-$ 2 sigma [16]. 
Kissimmee, FL

\section{A. Nozzle-Only Configuration}

The nozzle was run alone as a starting point to obtain the sonic boom signature of the model itself. Figure 8 shows the USM3D CFD solutions on the symmetry plane with the black line showing where the data was extracted 15 inches below the configuration. Figure 9 compares the experimental and computational pressure signatures at a distance of 15 inches away from the body. The shock off the nose of the cone starts at $X=-25$ inches and travels to $\mathrm{X}=-10$ inches where there is a compression wave from the change in geometry of the nose then the shock from the leading edge of the strut. An expansion from the nozzle geometry around $X=-2$ inches and the nozzle lip shock as well as the plume shock appear to coalesce and are at $X=5$ inches. Figure 9 shows that USM3D does an excellent job of matching the strength of the shock and compressions from the model.

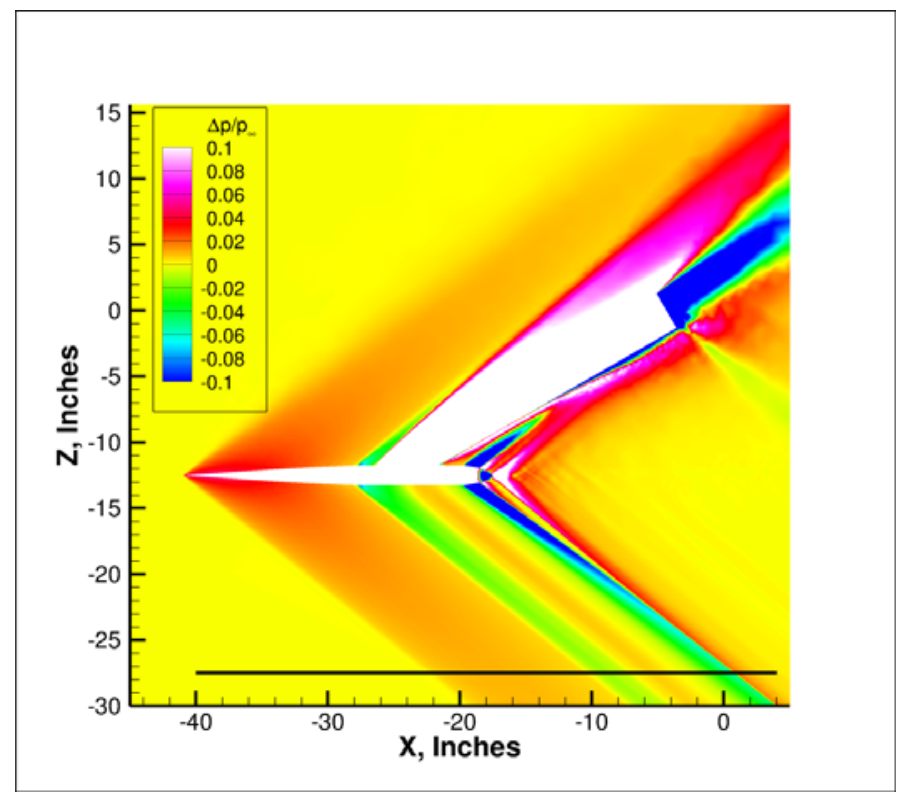

Figure 8. Symmetry cut of $\Delta \mathrm{P} / \mathrm{P}_{\infty}$ of nozzle-only configuration at Mach 1.6, $\mathbf{R e}=$ $3.5 \times 10^{6} / \mathrm{ft}, \alpha=0.0^{\circ}, H_{\text {nose }}=15$ inches. 
Kissimmee, FL

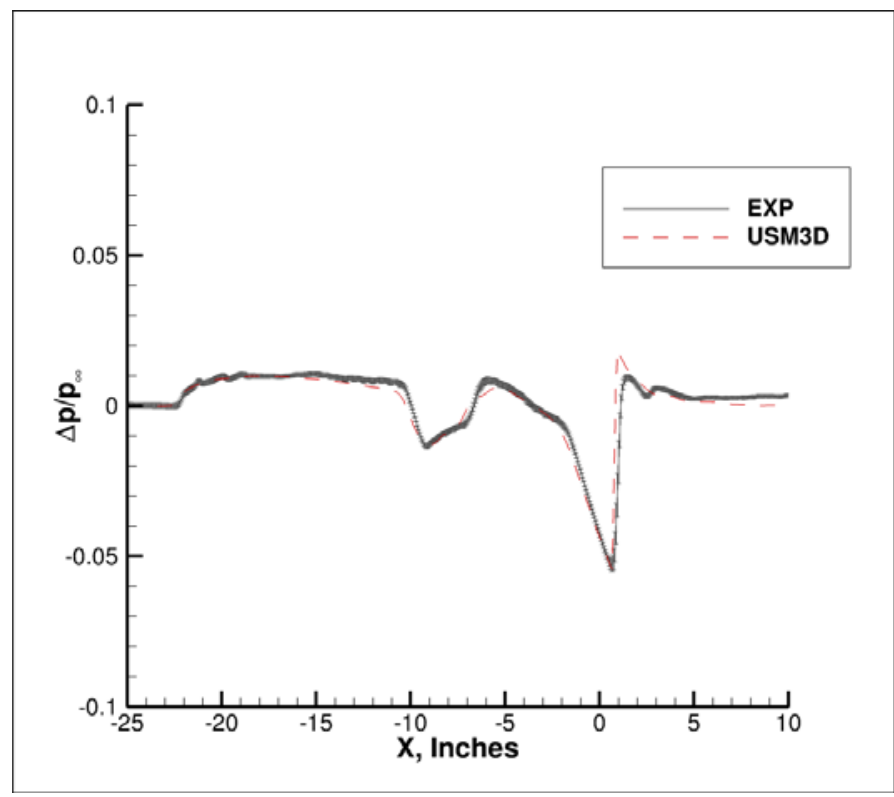

Figure 9. Comparison of experimental and computational $\Delta \mathrm{P} / \mathrm{P}_{\infty}$ of nozzle-only configuration at Mach 1.6, $R e=3.5 \times 10^{6} / \mathrm{ft}, \alpha=0.0^{\circ}, H_{n o s e}=15$ inches.

\section{B. Swept Aft Deck Configuration}

As discussed previously, the swept aft deck was designed to shield the plume effects from the signature. Figure 10 shows the symmetry cut of $\Delta \mathrm{P} / \mathrm{P}_{\infty}$ of the aft deck USM3D solution. The black horizontal line near the bottom of the figure depicts the location of the extracted pressure signature at 15 inches below the configuration. The deck reflects the disturbances upward while producing a small shock itself around the $\mathrm{X}=2$ inch mark. Figure 11 compares the USM3D and experimental boom signatures. The USM3D results are in good agreement, visually, with experimental data except at an axial location approximately between -8 inches $<\mathrm{X}<-2$ inches where wind tunnel data is slightly higher than USM3D results. This region corresponds to an overpressure in the flow field due to the sting. 
Kissimmee, FL

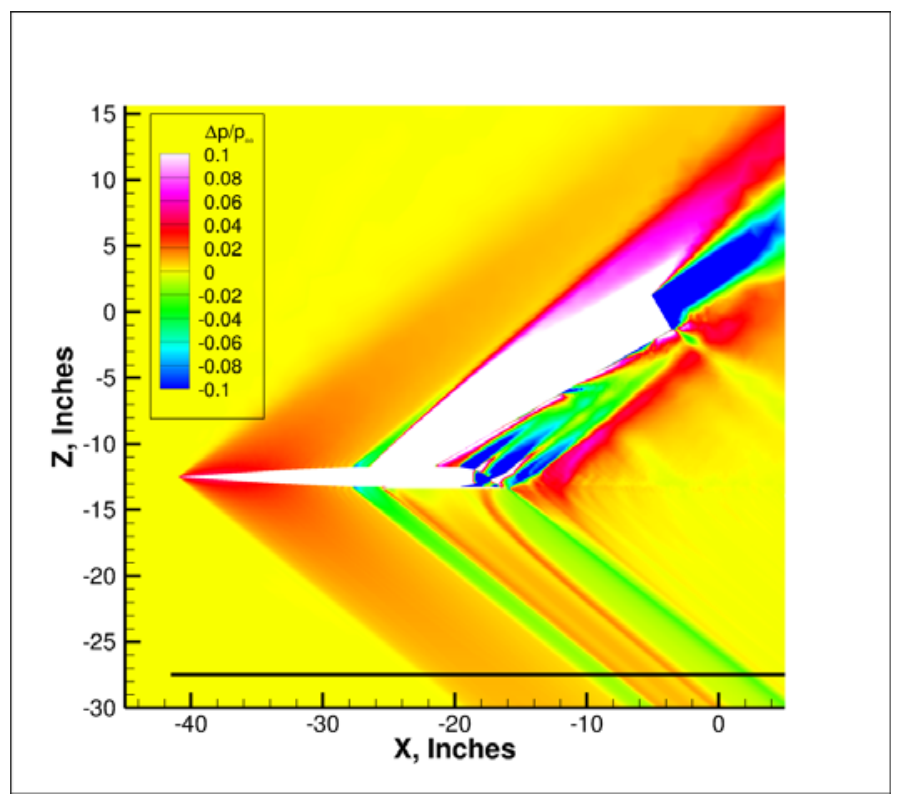

Figure 10. Symmetry cut of $\Delta \mathrm{P} / \mathrm{P}_{\infty}$ of swept aft deck configuration at Mach 1.6, $\mathrm{Re}=$ $3.5 \times 10^{6} / \mathrm{ft}, \alpha=0.0^{\circ}, H_{\text {nose }}=15$ inches.

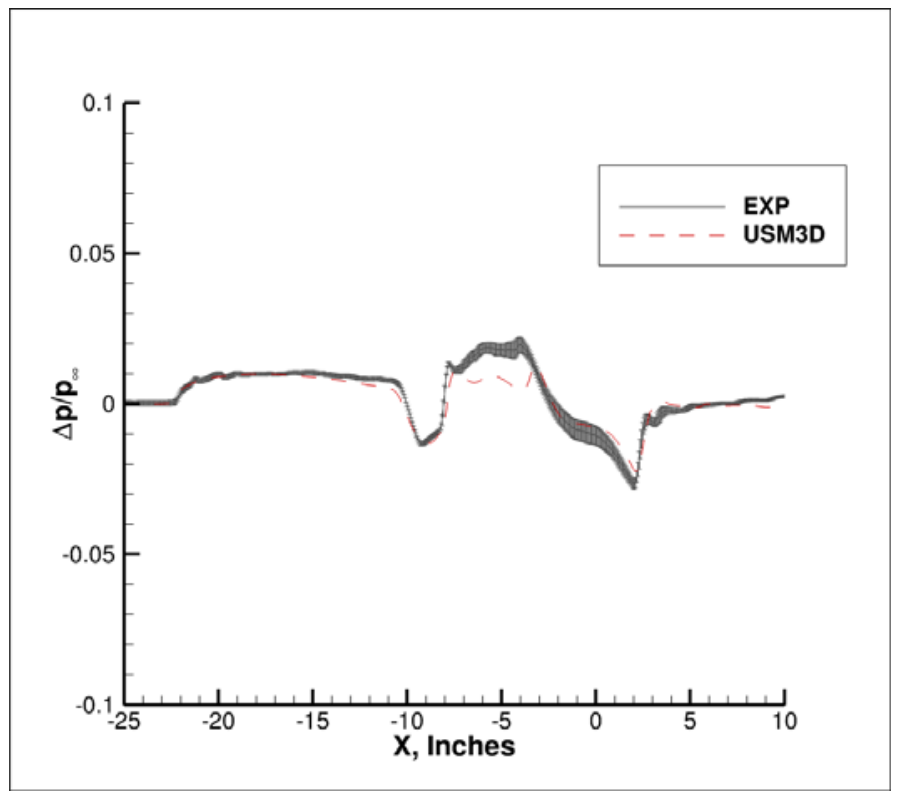

Figure 11. Comparison of experimental and computational $\Delta \mathrm{P} / \mathrm{P}_{\infty}$ of aft-swept-deck configuration at Mach 1.6, $\operatorname{Re}=3.5 \times 10^{6} / \mathrm{ft}, \alpha=0.0^{\circ}, \mathrm{H}_{\text {nose }}=15$ inches. 
Kissimmee, FL

\section{Biconvex Tail Configuration}

Figure 12 shows the Biconvex Tail Configuration computational solution symmetry plane with $\Delta \mathrm{P} / \mathrm{P}_{\infty}$. The black horizontal line near the bottom of the figure depicts the location of the extracted pressure signature at 15 inches below the configuration. Figure 13 shows the comparison of USM3D and wind tunnel averaged near-field pressure signatures. The USM3D results are in excellent agreement with wind tunnel data. USM3D accurately captured the front part of the signature, as well as oblique shocks from the nozzle lip at $\mathrm{X} \sim 2$ inches.

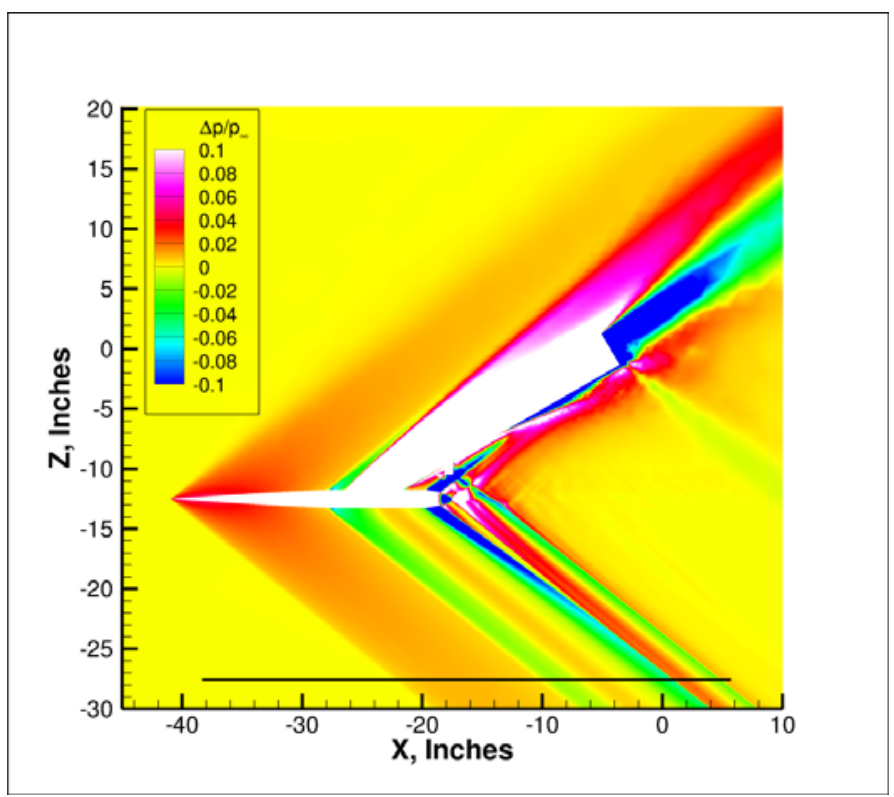

Figure 12. Symmetry cut of $\Delta \mathrm{P} / \mathrm{P}_{\infty}$ of the biconvex tail configuration, $\mathrm{M}_{\infty}=1.6, \mathrm{Re}=$ $3.5 \times 10^{6} / \mathrm{ft}, \alpha=0.0^{\circ}, H_{n o s e}=15$ inches. 
Kissimmee, FL

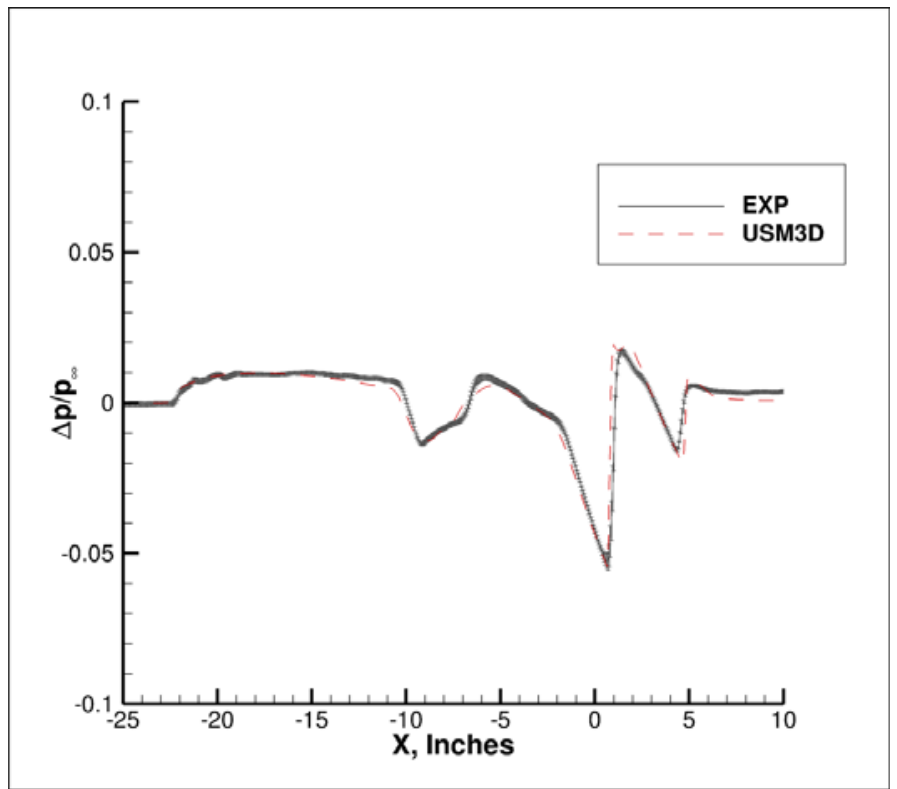

Figure 13. Comparison of experimental and computational $\Delta \mathrm{P} / \mathrm{P}_{\infty}$ of biconvex tail configuration at Mach 1.6, $\mathrm{Re}=3.5 \times 10^{6} / \mathrm{ft}, \alpha=0.0^{\circ}, \mathrm{H}_{\mathrm{nose}}=15$ inches.

\section{LaRC 25-D Tail Configuration}

As mentioned previously, USM3D simulations of the LaRC 25-D tail configuration were performed at a freestream Mach number of 2.0. Figure 14 shows the USM3D CFD solutions on the symmetry plane with the black line showing where the data was extracted at 15 inches below the configuration. The computational model has a very strong shock at $\mathrm{X}=0$ inches at the rail location. Figure 15 shows the comparison of USM3D and wind tunnel averaged near-field pressure signatures. The USM3D results are in excellent agreement with wind tunnel data in the front and aft part of the signature. However, the computational does not quite match the sharpness of the shock at $x=0$. And slight discrepancies can be observed at X $~ 8.5$ and 17 inches where USM3D predicts stronger shocks than wind tunnel data. This might be due to rounding of shock waves during the averaging process of the wind tunnel data. 
Kissimmee, FL

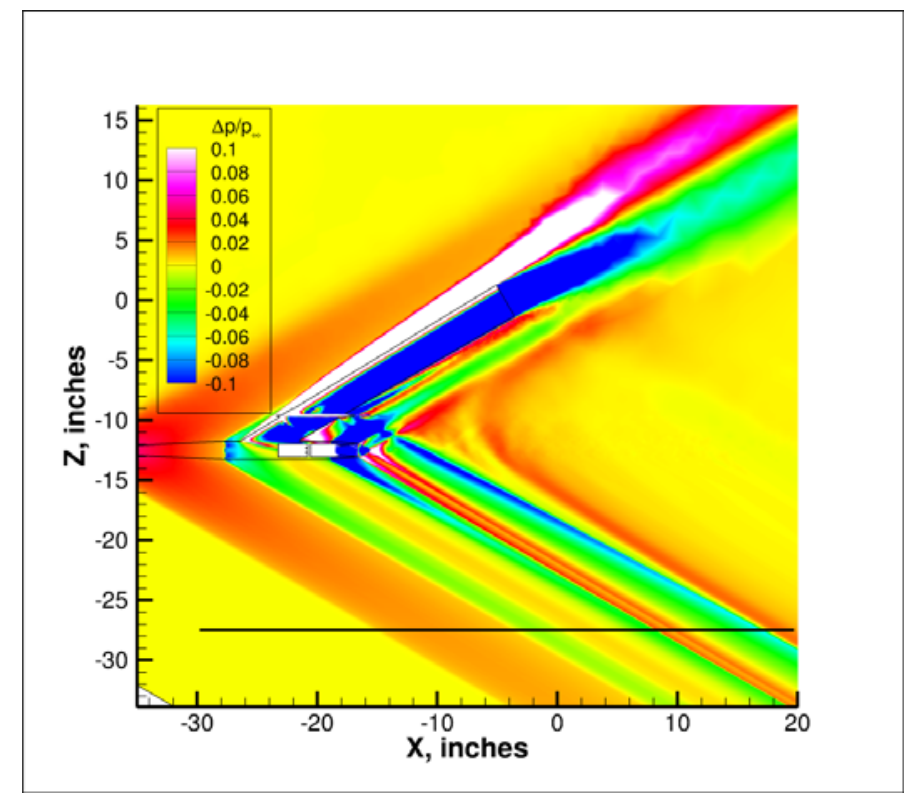

Figure 14. Symmetry cut of $\Delta \mathrm{P} / \mathrm{P}_{\infty}$ of the LaRC 25-D tail configuration, $\mathrm{M}_{\infty}=\mathbf{2 . 0}$, $\mathrm{Re}=3.5 \times 10^{6} / \mathrm{ft}, \alpha=0.0^{\circ}, H_{\text {nose }}=15$ inches.

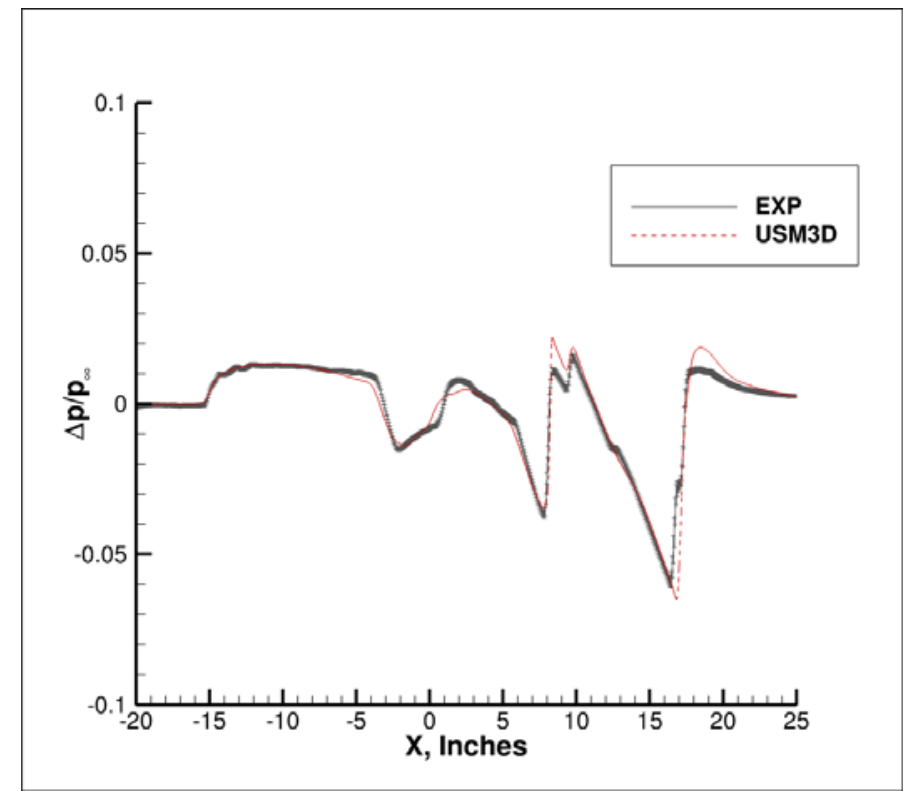

Figure 15. Comparison of experimental and computational $\Delta \mathrm{P} / \mathrm{P}_{\infty}$ of $25-\mathrm{D}$ tail configuration at Mach 2.0, $\operatorname{Re} 3.5 \times 10^{6} / \mathrm{ft}, \alpha=0.0^{\circ}, H_{n o s e}=15$ inches. 
Kissimmee, FL

\section{E. Double Wedge Configuration}

USM3D simulations for the double wedge configuration was performed for a freestream Mach number of 2.0 and unit Reynolds number equal to $3.5 \times 10^{6}$ per $\mathrm{ft}$ to match the conditions in the Glenn 1x1 wind tunnel. Figure 16 shows the Double Wedge Configuration symmetry plane colored with USM3D pressure coefficient contours. The black horizontal line near the bottom of the figure depicts the location of the extracted pressure signature at 15 inches below the configuration. The double wedge was designed to give a stronger shock compared to the shock emanating from the Biconvex Tail Configuration. Figure 17 shows the comparison of USM3D and wind tunnel averaged near-field pressure signatures. The USM3D results are in excellent agreement with wind tunnel data in the front and aft part of the signature. Slight discrepancy can be observed at X 11 inches where USM3D predicts a stronger shock than wind tunnel data. This might be due to rounding of shock waves during the averaging process of the wind tunnel data.

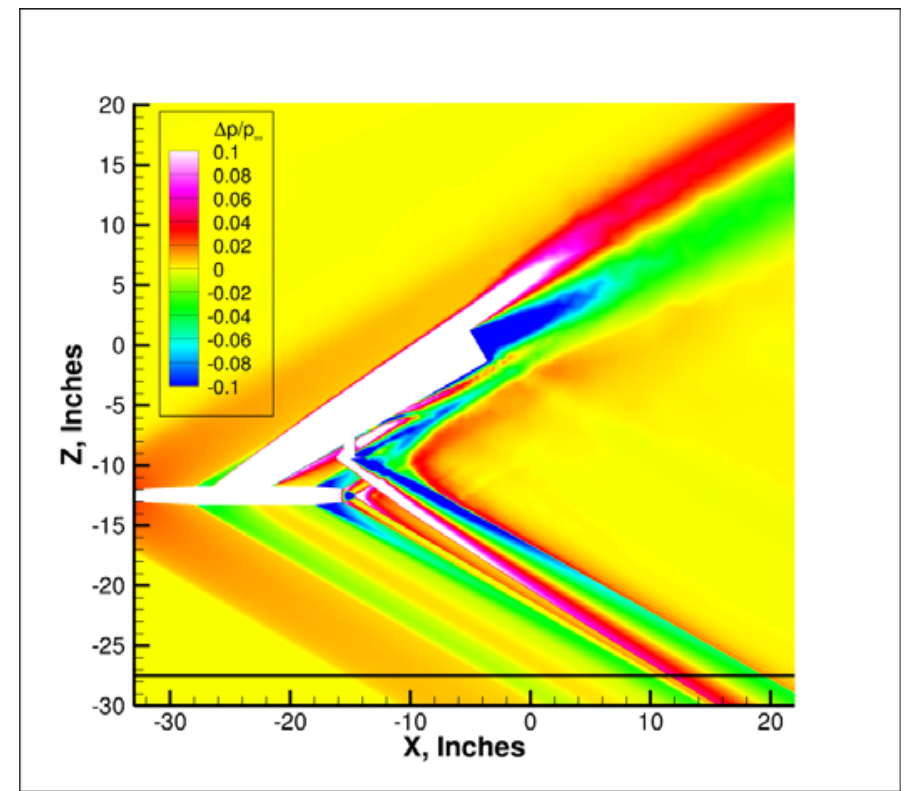

Figure 16. Symmetry cut of $\Delta \mathrm{P} / \mathrm{P}_{\infty}$ of the of the double wedge configuration, $M_{\infty}=2.0, R e=3.5 \times 10^{6} / \mathrm{ft}, \alpha=0.0^{\circ}, H_{n o s e}=15$ inches. 


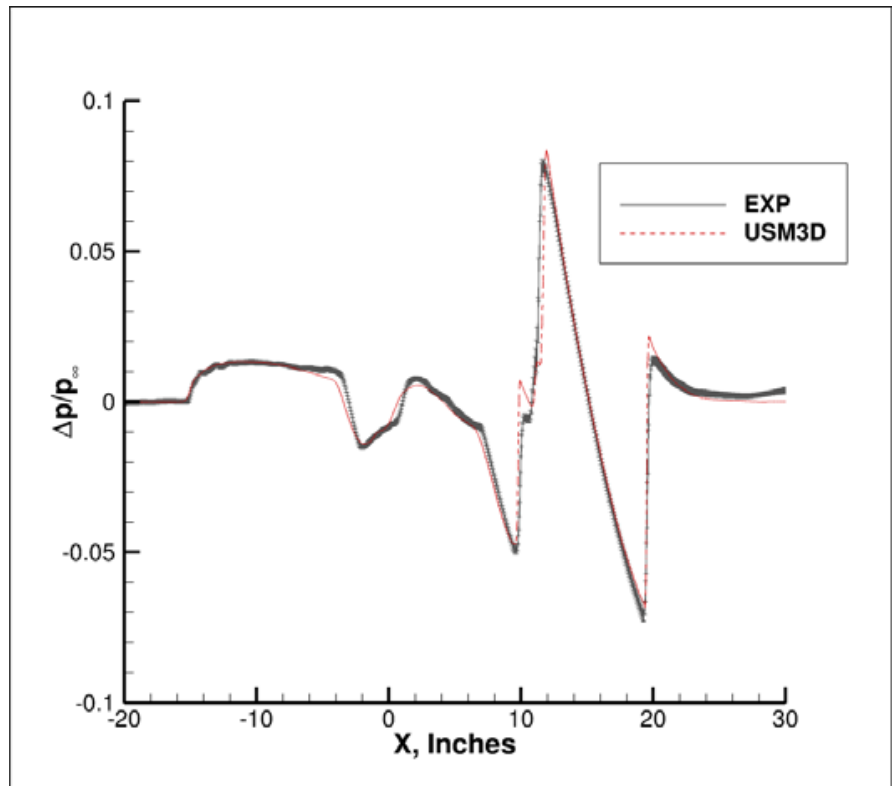

Figure 17. Comparison of experimental and computational $\Delta \mathrm{P} / \mathrm{P}_{\infty}$ of double wedge configuration at $M a c h 2.0, R e=3.5 \times 10^{6} / \mathrm{ft}, \alpha=0.0^{\circ}, H_{n o s e}=15$ inches.

\section{F. RBOS Comparisons}

RBOS images were obtained for each of the five configurations. Figures 18 through 20 compare the experimental RBOS images (in the vertical direction) with computed density gradients from the USM3D results for the nozzle alone, the aft-deck and the double wedge, respectively. These three configurations were chosen due to the ease of seeing the features in experimental images. Although further examination of the D-25 tail results using the RBOS would be very useful for investigating the difference between computational and experimental results, the shocks coming off the tail are not easily seen on the images.

In all three sets of images, the initial shock diamonds from the nozzle, and the shocks from the nozzle lips are easily seen in both the computational and experimental results. Figure 19 shows shocks impacting the aft-deck, which shields the rail from the impact in both sets of figures (computational and experimental). Finally, Figure 20 shows the strong shock from the double wedge passing through the plume flow and traveling to where the rail would be located. Overall, there is excellent agreement between the RBOS and computational results. 

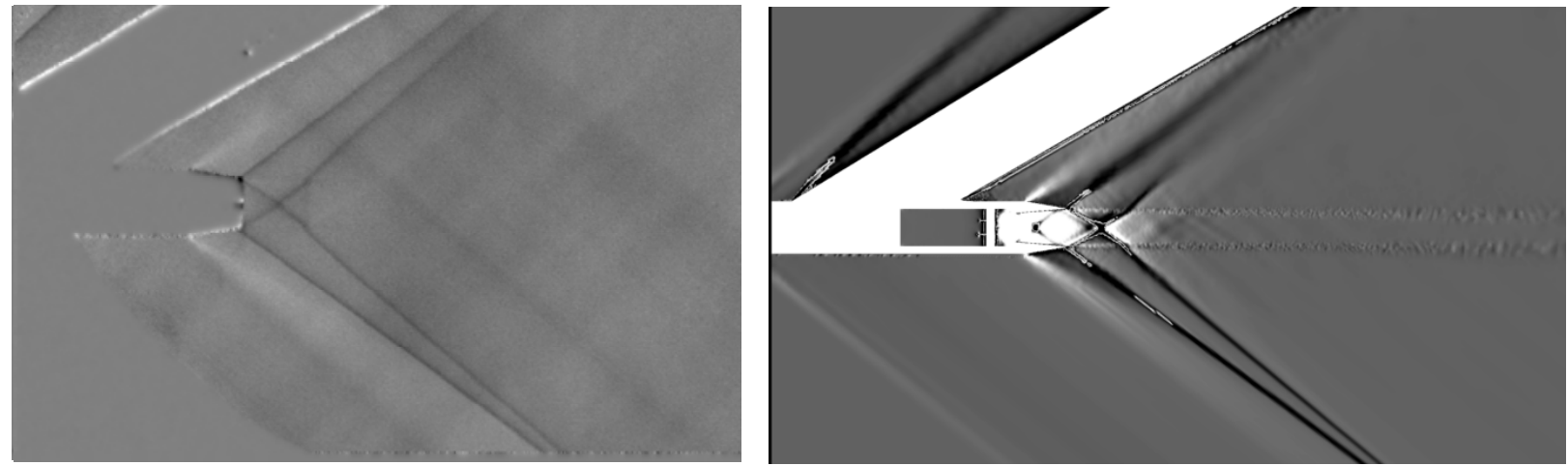

Figure 18. Nozzle-alone RBOS comparison at Mach 1.6, $\operatorname{Re}=3.5 \times 10^{6}, \alpha=0.0^{\circ}$

(experimental RBOS images left, USM3D density gradient images right).
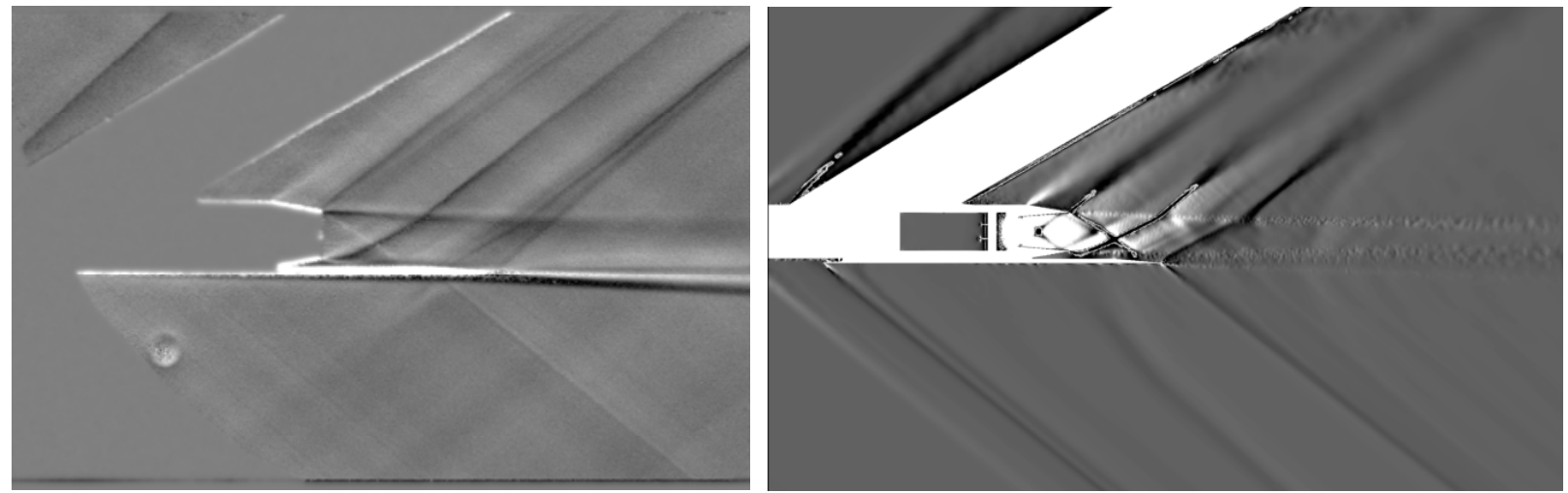

Figure 19. Aft deck $\mathrm{RBOS}$ comparison at Mach 1.6, $\mathrm{Re}=3.5 \times 10^{6}, \alpha=0.0^{\circ}$

(experimental RBOS images left, USM3D density gradient images right).
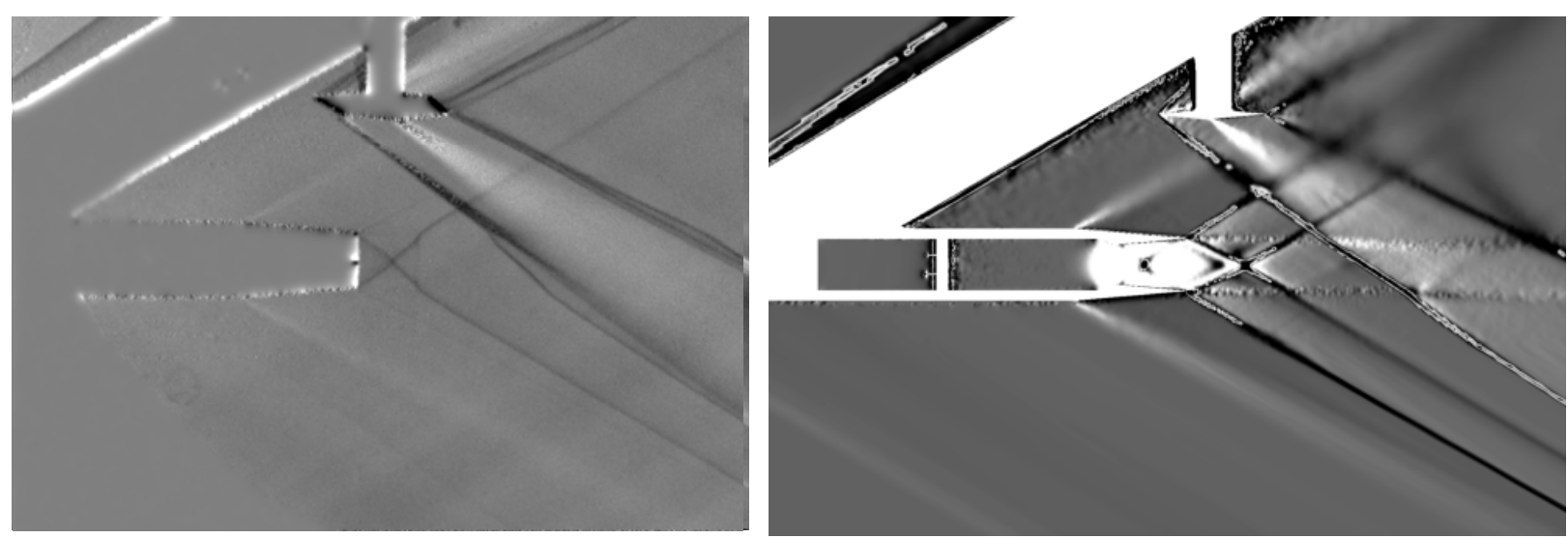

Figure 20. Double wedge $\mathrm{RBOS}$ comparison at Mach 2, $\mathrm{Re}=3.5 \times 10^{6}, \alpha=0.0^{\circ}$

(experimental RBOS images left, USM3D density gradient images right). 
Kissimmee, FL

\section{Conclusions}

A wind tunnel test was performed in the NASA Ames 9x7 Supersonic Wind Tunnel focusing on the shock waves traveling through and interacting with an exhaust nozzle plume. The main objective of the study was to identify jet plume and plume-shock interaction effects and identify the potential for those effects to impact a low boom aircraft design. The study was also used to develop and validate the CFD capability required to accurately include nozzle flow with impinging shock effects on near field and ground-propagated sonic boom signatures.

Three different aft body representations, each creating a different shock wave signature that passed through the plume, were tested. An aft deck configuration, where part of the aircraft shields the nozzle plume, and the nozzle only configurations were also tested. The pressure signatures created by the plume and shock generators, were captured using a 14-inch pressure rail. Retroreflective Background-Oriented Schlieren (RBOS) was also used to obtain schlieren images of the flow field around the model and behind the model, where the shock from the shock generators passed through the plume.

USM3D RANS simulations were conducted for all five configurations. The USM3D results were in excellent agreement with the wind tunnel averaged pressure signatures. USM3D RANS computational results also compared well to the RBOS images obtained with the initial nozzle shock structure easily seen in both sets of images as well as the shocks forming off the nozzle, aftbody or double wedge.

\section{Acknowledgements}

The research reported in this paper was sponsored by the NASA Fundamental Aeronautics Program Commercial Supersonics Technology Project.

\section{References}

1 Maglieri, D., Bobbitt, P., Plotkin, K., Shepherd, K., Coen, P., Richwine, D., "Sonic Boom: Six Decades of Research." NASA/SP-2014-622, December 2014.

2 Durston, D., Cliff, S., Denison, M., Smith, N., Heineck, J., Schairer, E., Kushner, L., Castner, R., Elmiligui, A., Carter, M., Winski, C., Shea, P., Blumenthal, B., "Nozzle Plume/Shock Interaction Sonic Boom Test Results from the NASA Ames 9- by 7-Foot Supersonic Wind Tunnel." AIAA 2017-0041, January 2017.

3 Putnam, L. and Capone, F., "Experimental Determination of Equivalent Solid Bodies to Represent Jets Exhausting into a Mach 2.20 External Stream,” NASA TN-D-5553. 
4 Barger, R. L. and Melson, N. D., "Comparison of Jet Plume Shape Predictions and Plume Influence on Sonic Boom Signature," NASA TP-3172.

5 Castner, R. S., "Exhaust Nozzle Plume Effects on Sonic Boom," Journal of Aircraft, 2012, vol. 49: 415422, March-April 2012.

6 Castner, R., Cliff, S., Elmiligui. A., and Winski. C., "Plume and Shock Interaction Effects on Sonic Boom in the 1-foot by 1-foot Supersonic Wind Tunnel", AIAA 2015-1046, Jan. 2015.

7 Test Planning Guide for High Speed Wind Tunnels, http://www.nasa.gov/sites/default/files/643643main_HSpeedTestPlanGuide.pdf.

NASA Ames Wind Tunnel Operations Division report number A027-9391-XB2, rev. 5, April 27, 2005.

8 Reed, T. D., Pope, T. C., and Cooksey, J. M.: Calibration of Transonic and Supersonic Wind Tunnels. NASA CR-2920, November 1977.

9 Carlson, Harry W., Mack, Robert J., and Morris, Odell A.: A Wind-Tunnel Investigation of the Effect of Body Shape on Sonic-Boom Pressure Distributions. NASA TN D-3106, November 1965.

10 Cliff, S., "On the Design and Analysis of Low Sonic Boom Configurations," NASA Conference Publication 10133, High Speed Research: Sonic Boom volumes I and II, Presented at the High Speed Research Sonic Boom Workshop, Ames Research Center, May 12-14, 1993.

11 Ordaz, I., Wintzer, M., and Rallabhandi, S.: Full-Carpet Design of a Low-Boom Demonstrator Concept. AIAA Paper 2015-2261, 33rd AIAA Applied Aerodynamics Conference Dallas, TX, June 2015.

12 Cliff, S., Denison, M., Moini-Yekta, S., Morr, D., and Durston, D., "Wind Tunnel Model Design for Sonic Boom Studies of Nozzle Jet Flows with Shock Interactions," AIAA 2016-2035, SciTech 2016, 54th Aerospace Sciences Meeting, San Diego, Jan 8, 2016.

13 Cliff, S., Elmiligui, A., Aftosmis, A., Thomas, S., Morgenstern, J., and Durston, D.: Design and Evaluation of a Pressure Rail for Sonic Boom Measurements in Wind Tunnels. ICCFD7-2006, Seventh International Conference on Computational Fluid Dynamics (ICCFD7), Big Island HI, July 2012.

14 Schairer, E., Kushner, L., Drain, B., Heineck, J., and Durston, D.: Stereo Photogrammetry Measurements of the Position and Attitude of a Nozzle-plume/Shock-wave Interaction Model in the NASA Ames 9- by 7- Ft Supersonic Wind Tunnel. 55th AIAA Aerospace Sciences Meeting, Grapevine TX, January 9-12, 2017.

15 Nathanial T. Smith, Donald A. Durston, and James T. Heineck: Retroreflective Background Oriented Schlieren Imaging Results from the NASA Plume-Shock Interaction Test. 55th AIAA Aerospace Sciences Meeting, Grapevine TX, January 9-12, 2017.

16 Durston, D., Elmiligui, A., Cliff, S., Winski, C., Carter, M., and Walker, E.: Experimental and Computational Sonic Boom Assessment of Boeing N+2 Low Boom Models. NASA/TP-2015-218482, January 2015.

17 Frink, N. T., Pirzadeh, S. Z., Parikh, P. C., Pandya, M. J., and Bhat, M., "The NASA Tetrahedral Unstructured Software System (TetrUSS)," The Aeronautical Journal, Vol. 104, No. 1040, October 2000, pp. 491-499.

18 Lohner R and Parikh P., "Three-Dimensional Grid Generation by the Advancing Front Method." Int.J.Num.Meth. Fluids 8, pp 1135-1149 (1988).

19 Pirzadeh S., "Three-dimensional unstructured viscous grids by the advancing layers method." AIAA Journal, Vol. 34, No. 1, January 1996, pp. 43-49.

20 Pirzadeh S., "Advanced Unstructured Grid Generation for Challenging Aerodynamics Applications." AIAA-2008-7178, August 2008.

21 Frink, N. T., "Three-Dimensional Upwind Scheme for Solving the Euler Equations on Unstructured Tetrahedral Grids", Ph. D. Dissertation, Virginia Polytechnic Institute and State University, September 1991.

22 Roe, P., "Characteristic Based Schemes for the Euler Equations." Annual Review of Fluid Mechanics, Vol. 18, 1986, pp. 337-365.

23 Spalart, P.; and Allmaras, S.A., "One-equation turbulence model for aerodynamic flows." AIAA 920439, January 1992.

24 Menter, F.R., "Improved Two-Equation k-omega Turbulence Models for Aerodynamic Flows." NASA TM- 103975, October 1992. 
Kissimmee, FL

25 Pandya, M.J.; Abdol-Hamid, K.Z.; and Frink, N. T., "Enhancement of USM3D Unstructured Flow Solver for High-Speed High-Temperature Shear Flows.” AIAA-2009-1329, January 2009.

26 Nayani, S. N.; and Campbell, R. L., "Evaluation of Grid Modification Methods for On- and Off-Track Sonic Boom Analysis.” AIAA-2013-0798, January 2013. 